\title{
Article
}

\section{Forest Dynamic in the Italian Apennines}

\author{
Enrico Pallotta ${ }^{1}$, Lorenzo Boccia ${ }^{2, *} \mathbb{C}$, Carlo Maria Rossi ${ }^{1}$ and Maria Nicolina Ripa ${ }^{1}(\mathbb{C}$ \\ 1 DAFNE—Department of Agriculture and Forest Science, University of Tuscia, 01100 Viterbo, Italy; \\ enricop92@live.it (E.P.); carlomariarossivt@gmail.com (C.M.R.); nripa@unitus.it (M.N.R.) \\ 2 Department of Architecture, University of Naples, Federico II, 80138 Naples, Italy \\ * Correspondence: lorenzo.boccia@unina.it
}

Citation: Pallotta, E.; Boccia, L.;

Rossi, C.M.; Ripa, M.N. Forest

Dynamic in the Italian Apennines.

Appl. Sci. 2022, 12, 2474. https://

doi.org/10.3390/app12052474

Academic Editor: Joao Carlos

Andrade dos Santos

Received: 11 November 2021

Accepted: 23 February 2022

Published: 27 February 2022

Publisher's Note: MDPI stays neutral with regard to jurisdictional claims in published maps and institutional affiliations.

Copyright: (C) 2022 by the authors. Licensee MDPI, Basel, Switzerland. This article is an open access article distributed under the terms and conditions of the Creative Commons Attribution (CC BY) license (https:// creativecommons.org/licenses/by/ $4.0 /)$.

\begin{abstract}
In recent decades, many mountain areas of the Mediterranean countries show spontaneous reforestation or densification due to depopulation and the consequent abandonment of traditional agricultural and pastoral activities, leading to the loss of open habitats. In this paper, dynamics of natural and semi-natural areas in the summit areas of the Abruzzo, Lazio e Molise National Park are investigated, highlighting changes that occurred from 1954 to present days. Historic Land cover maps have been produced by photo interpretation. A quantitative description of changes and habitats loss in relation to the socio-economic changes is provided. As expected, a forest surface expansion and an open areas decrease are observed similarly to many marginal mountains, where land abandonment and general forest/shrub recovery are the inevitable tendencies. An intense debate is still ongoing regarding the opportunity of rewilding, allowing the natural reforestation processes, versus the management of some areas, in order to preserve habitats and cultural traditional landscapes. For the EU biodiversity conservation policy to be effective, proper planning and management of interventions as well as public support and funding, become crucial when traditional activities are no longer profitable and viable for local inhabitants.
\end{abstract}

Keywords: forest-grassland dynamics; reforestation; land abandonment; LULC analysis

\section{Introduction}

According to Forman et al. (1986) [1], the landscape can be defined as "a heterogeneous land area composed of a cluster of interacting ecosystems that is repeated in similar form throughout". By its nature, the landscape is a complex system which has to be considered as holistic (the whole is greater than the sum of its parts), relativistic and dynamic: changing an element always means, in some way, changing the whole. This is the reason why some complex systems have been found to reorganize themselves so drastically that they really become something new [2].

Anthropogenic activities are responsible for many changes in the heterogeneous scale and patterns of landscape [3] and a modification is also expected when the anthropogenic pressure decreases [4]. A pan-European scale study over the last 25 years revealed that the most important landscape transitions are urbanization and natural afforestation processes [5].

Currently, more than half of the Earth's terrestrial surface is shaped by agro-pastoral activities, including a high fraction of protected areas [6]. Over time these practices originated landscapes which can be defined as traditional, and which played an important role in creating new high-quality habitats, which evolved into unique and characteristic biodiversity [7-9].

Traditional landscapes are defined as those that have a distinct and recognizable structure resulting from the integration of abiotic, biotic and cultural elements over the centuries and through slow development processes characterized by few periods of change and long periods of consolidation [10]. 
In Italy, a relevant example of traditional landscape can be found in the Apennines, that are a mountain range of about $1350 \mathrm{~km}$ from northwest to southeast Italy. Until 1900 , traditional agricultural and forestry practices in these areas have altered the natural landscapes, resulting in a complex mosaic of sparse open areas and woodland patches [4].

Many Italian regions, including the Apennines, were affected by the decline of the traditional agro-pastoral activities that occurred as a result of the deep socio-economic changes after WW2 and then by the economic boom that followed [11-13]. The diffusion of intensive farming in favorable areas and the urbanization in the lowlands also triggered the abandonment of mountain areas and, consequently, of seasonal mountain pastures. This phenomenon was also common in many southern European mountain regions, where the processes of urbanization and the contemporary decline of agricultural activities have led to changes in rural land use practices, that since the 1950s have often caused the complete abandonment of agricultural land and of traditional activities [14].

As a consequence of this social phenomenon a progressive renaturalization of rural areas and of open grazing areas occurred in the Apennines and in other Mediterranean mountain regions such as Spain [15], France [16], Greece [17,18].

As the dynamics and magnitude of the changes increased, the traditional landscape structure was, therefore, greatly disturbed [19] also as a consequence of a change at the plant community level [12,16,20,21].

Natural succession processes, with shrub and woodland encroachment $[4,11,20,22]$, led to a return to a seminatural state showing an increase in size and number of woodland patches [19]. Forest expansion occurred both in terms of the gap filling process at a lower elevation and as an upward shift of the treeline [23]. As reported in Garbarino et al. [11], the increase of Italian forests is sizable; forests measured as a square kilometer, shifted from 60,000 in 1936 (Italian Kingdom Forest Map) to 85,000 km² in 1985 (First Italian Forest Inventory, IFNI85), and to 105,000 in 2005 (Second Italian Forest Inventory, INFC05) and it was estimated at about $110,000 \mathrm{~km}^{2}$ in 2015 , with an increase of $20 \%$ in the last 30 years [24].

Land use land cover (LULC) change is reported by many authors as the single most important driver of biodiversity and geodiversity loss. This problem also affects legally protected areas where the objective of conservation should be carefully analyzed since different management strategies and intervention may deeply affect the future ecosystem services provision [25-27]. The precise implications of landscape transformation for species and habitat conservation are not sufficiently known and are still being debated in the scientific literature; changes in landscape composition and configuration due to management abandonment, in fact, can affect biodiversity both positively and negatively [28,29].

Abandonment can provide a unique opportunity for the regeneration of native ecosystems with a high nature value, such as native forests, and the reduced anthropogenic pressure and forest restoration could favor several forest species in Europe [12,30].

On the other side, several studies describe how the progressive abandonment of agricultural activities in these areas reduces landscape heterogeneity and has been often accompanied by a biodiversity decline.

In Europe, where a high portion of species is dependent on the persistence of traditional rural landscapes, habitat loss caused by land-use change and abandonment of traditional activities is considered one of the main threats to biodiversity by some authors. In their study, Laiolo et al. refers to the detrimental effect on several grassland bird species that are dependent upon grazed pastures [31]. As a consequence of landscape homogenization, the extent of such ecotones has been greatly reduced in Central Europe. Although not so much is known about the effects of ecotone loss on biodiversity in general, however, it seems obvious that the numerous species specialized on these complex habitats-such as the Ring Ouzel - may be negatively affected by the expansion of forests [32]. Recently established forests remain different from ancient forests in terms of herbaceous plant species composition even hundreds of years after re-establishment [33]. Tree encroachment usually results in a simplification and homogenization of these landscapes [12], with a decrease in landscape diversity and a reduction in mosaics complexity and in forest grassland eco- 
tones due to forest gap-filling processes $[4,19,34]$. Species well suited to semi-natural open habitats may be negatively impacted by the expansion of forests [4,35]; also, a reduction in ecological connectivity across open semi-natural habitats, such as meadows and pasturelands, can be expected [36]. Nevertheless, the disappearance of some forms of land use linked to traditional activities determines a decrease in culturally important landscapes that have become, over time, the identity and expression of the culture of the territory [18,37].

The cultural importance of traditional agriculture landscapes has been widely recognized in Europe and in the world. UNESCO world heritage provides a "cultural landscapes" category where sites of traditional or symbolical agricultural practices are inscribed. Labeled "Globally Important Agricultural Heritage Systems" (GIAHS), The Food and Agriculture Organization (FAO) in 2002 launched the Globally Important Agricultural Heritage Systems (GIAHS) program with the aim of identifying agricultural systems of global importance; preserving landscapes, agrobiodiversity and traditional knowledge, and applying the dynamic conservation principles while promoting sustainable development [38,39].

Land use land cover (LULC) change is reported as the single most important driver of biodiversity and geodiversity loss. This problem also affects legally protected areas. The conservation focus (pre- or post-abandonment) in different regions is an important factor influencing how scientists address the abandonment issue, and this may affect how land-use policies are defined in agricultural landscapes [29].

In this perspective, it could be essential that these semi-natural landscapes are maintained for the successful long-term conservation of biodiversity. Conservation of biodiversity cannot rely only on the preservation of intact refuges in protected areas, but it requires a common perspective with agro-pastoral activities in a well-balanced way by applying a landscape scale approach in conservation management [40].

The study aims at analyzing spatiotemporal changes in complex landscapes, occurred during about 60 years in a study area of the Abruzzi, Lazio, and Molise National Park focusing on the areas above $1300 \mathrm{~m}$ asl.

The study intends to quantitatively analyze the transformation dynamics of tree, shrubs and grass cover influenced by different amounts of anthropogenic pressure, and to identify the driving forces responsible for these dynamics. Another aim is also to determine how the results can help produce appropriate guidelines for the land management in these traditional landscapes which represent an important heritage, also from a cultural point of view.

\section{Materials and Methods}

\subsection{Study Area and Land Use Story}

The Abruzzo, Lazio and Molise National Park (ALMNP) was established in 1922 and has an extension of $500 \mathrm{~km}^{2}$ in addition to another $770 \mathrm{~km}^{2}$ of external protection areas (ZPE). The bear, the wolf and the chamois are the animal species symbolizing the park, but quite a number of species and habitats are also protected inside the park. Its elevation ranges from 900 to $2200 \mathrm{~m}$ asl, the latitude is between $41^{\circ} 36^{\prime}$ and $42^{\circ} 00^{\prime} \mathrm{N}$ and the longitude between $13^{\circ} 39^{\prime}$ and $14^{\circ} 01^{\prime}$. The climate is maritime (dry season in the hot quarter) and in the 4 measuring stations (Barrea $1000 \mathrm{~m}$ asl, Castel di Sangro $805 \mathrm{~m}$ asl, Pescasseroli $1150 \mathrm{~m}$ asl, Scanno $1030 \mathrm{~m}$ asl) the annual rainfall is between 800 and $1150 \mathrm{~mm} /$ year; the climate can be classified $\mathrm{Cfb}$ according to the classification of Köppen Geiger (Humid temperate climate and average temperature of the hottest month below $22^{\circ} \mathrm{C}$ ). Sixty percent of the park (about 30,000 ha) is covered by woods; the vegetation is dominated by broadleaf species of the Mediterranean biomes whose $73 \%$ is represented by beech forest, mainly high forest or coppice in conversion into high stem; over $30 \%$ is covered by high-mountain grasslands together with meadows and clearings. The main Land Cover classes of the ALMNP are summarized in Table 1. 
Table 1. Main current land cover class in the Abruzzo, Lazio e Molise National Park.

\begin{tabular}{ccc}
\hline Cover Class & $\begin{array}{c}\text { CORINE LAND COVER } \\
\text { Code (Adapted) }\end{array}$ & Incidence \% \\
\hline Artificial surfaces & 1 & 0.5 \\
\hline Arable land & 21 & 1.3 \\
\hline Permanent crops & 22 & 0.0 \\
\hline Heterogeneous agricultural areas & 24 & 4.2 \\
\hline Pastures & 231 & 0.4 \\
\hline Turkey oak forests & $311-1$ & 3.1 \\
\hline Hop-hornbeam mixed forests & $311-2$ & 2.6 \\
\hline Beech forests & $311-3$ & 42.7 \\
\hline Broad-leaved forests Other forest species & 311 & 7.9 \\
\hline Coniferous tree planting & 312 & 2.1 \\
\hline Natural grassland and moors and heathland & 32 & 23.9 \\
\hline Sparsely vegetated areas & 333 & 11.1 \\
\hline Water bodies & 5 & 0.2 \\
\hline
\end{tabular}

A depopulation rate of $57 \%$ from 1921 to 2020 characterizes the demography of the area against an increase of the Italian population of about $15 \%$ in the same century. In the 25 municipalities of the ALMNP, the population counted 61,433 inhabitants in 1921, 54,344 in 1951, 31,640 in 1991 and, nowadays, 25,986 inhabitants. Since the human activities, specifically pastoralism, have played a key role, in shaping and determining the landscape structure in the ALMNP, it now represents an interesting area to highlight the effects of abandonment. Furthermore, this territory has been affected for centuries by "transhumance" through tracks named "Tratturi" that have increased for centuries the number of grazing animals [41,42].

The selected study area (Figure 1) is the territory above $1300 \mathrm{~m}$ asl with a surface of about $82.83 \mathrm{~km}^{2} ; 25.20 \mathrm{~km}^{2}$ of them fall in the integral reserve area (A zone according to the Italian law), $53.62 \mathrm{~km}^{2}$ fall in the General reserve-oriented area (B zone according to Italian law) and only $1.30 \mathrm{~km}^{2}$ in the zone of development and social promotion (D Zone).

The reasons behind the choice of the study area are the following: (i) a prior investigation revealed an interesting land cover and land use change, with a relevant dynamics of the open areas above $1800 \mathrm{~m}$ and a dynamics of the edge [43]; (ii) in the past the area was interested by the "transhumance" that is recognized of great interest due to its important cultural legacy for agro-pastoral landscapes whose persistence is in crisis [44]; (iii) no similar landscape-change analysis has ever been carried out in this part of the Apennines [45].

\subsection{Land Cover Maps}

Dynamics of land cover have been analyzed, comparing the land cover maps (LULC) of 1954 and 2016. The adopted procedure is summarized in Figure 2. The aerial photographs of 1954 (named GAI flight-Italian Aeronautic Group) are the first complete coverage of the national territory; the flight was carried out in 1954-1956 with a scale approximatively of 1:35,000 (planimetric accuracy in the order of 5-7 $\mathrm{m}$ and a resolution up to $0.5 \mathrm{~m}$ ). Eleven images of 1954 were used and interpreted, using the package Image Analysis of ArcMap. The images were scanned with the Photogrammetric scanner of the IGMI (Italian Geographic Military Institute) at 2400 dpi. 


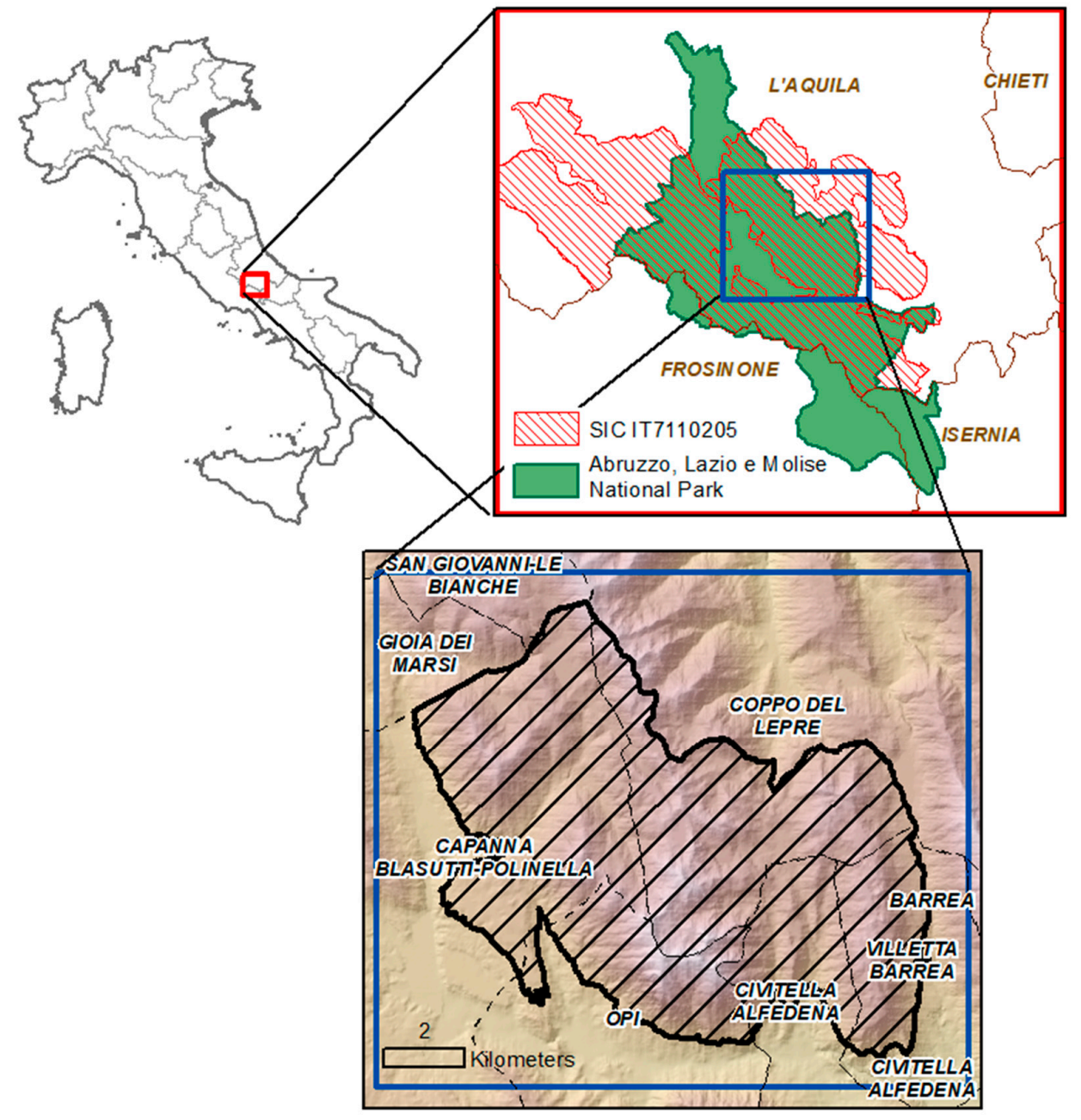

Figure 1. Study area.

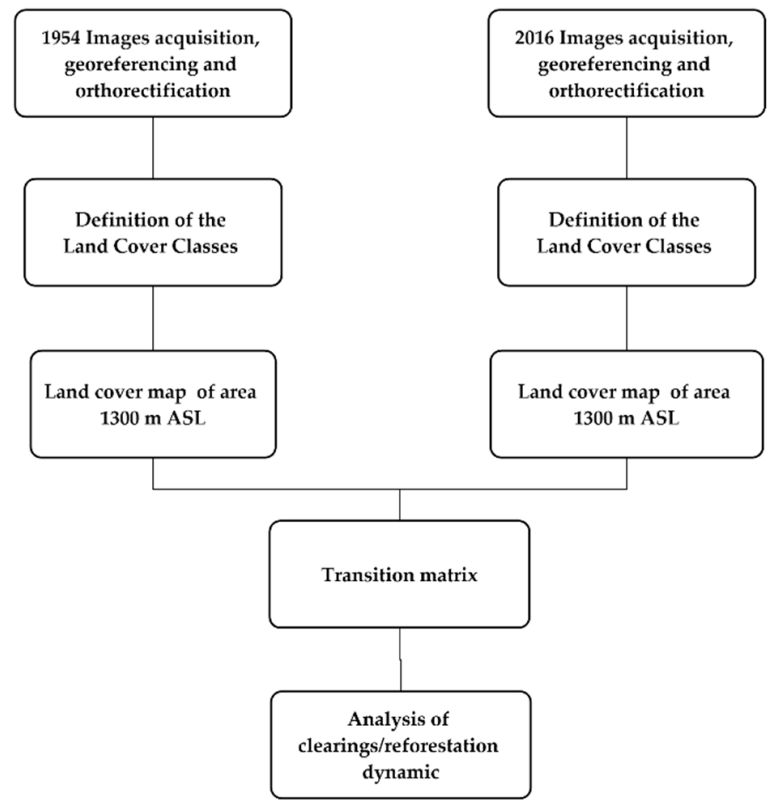

Figure 2. Scheme of the methodology adopted for the analysis of the dynamics of land cover in the study area. 
Georeferencing and orthorectification of the images has been carried out using 13 Ground Control Points (GCPs) for each frame extracted from Google Earth, and a DTM with ground accuracy of $40 \times 40 \mathrm{~m}$. The georeferencing system used is the WGS84 associated with the UTM projection. The study area is typically mountainous, and most of the support points have been identified in correspondence of rock formations, road crossings and buildings. Considering the absence of the fiduciary brands, a non-parametric model that allows the correspondence between image coordinates and ground coordinates through mathematical functions has been used [46]. It is a generalized model that does not require a priori knowledge of the parameters of the acquisition platform and projection system; therefore, it is widely applicable even with images without metadata [47].

The root mean squared error was $<2 \mathrm{~m}$. The coverage of the photos after the georeferencing and orthorectification procedure is shown in Figure 3.

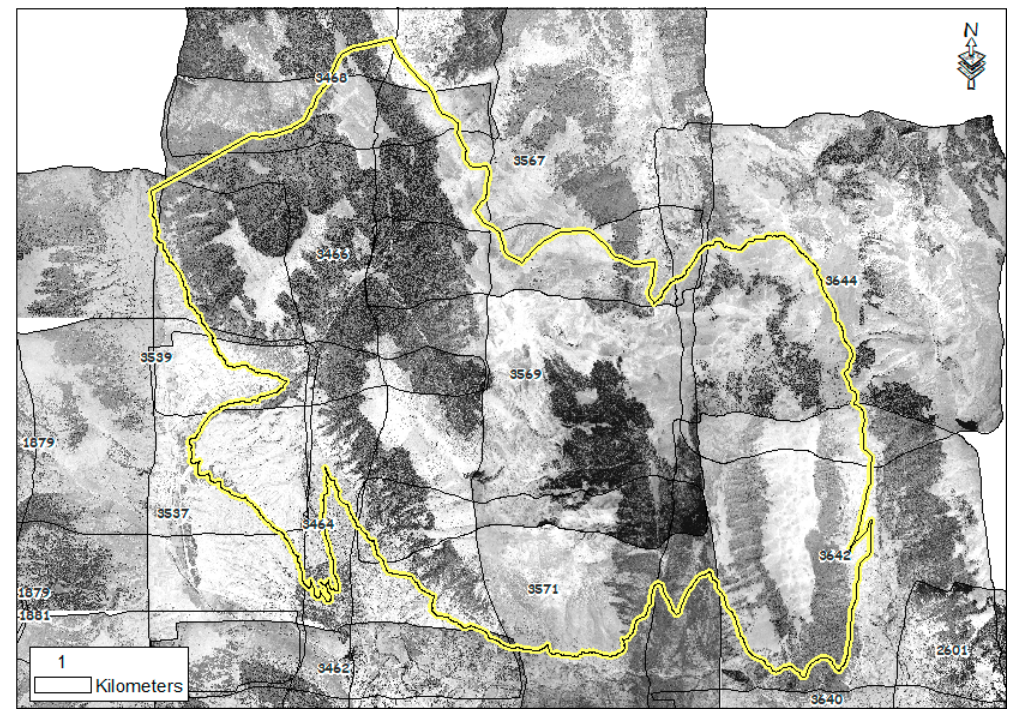

Figure 3. Coverage of the photos after orthorectification and georeferencing.

The current land use map was derived by available images in year 2016 of the app Google Earth Pro, obtained from aerial photos integrated with color ortophotos of 2007 and 2010. The interpretation was carried out according to the Italian Forestry Photo interpretation manual [48].

\subsection{Data Analysis}

The Land Cover maps obtained through photointerpretation showed 20 classes (Table 2, Figure A1) coded according to Corine Land Cover (CLC) up to the third level. CLC nomenclature does not distinguish the texture and the crown cover density of the forests and includes, for example, in the class 311 generically "deciduous and evergreen broad-leaved tree species with $>75 \%$ cover". Nevertheless, a different degree of canopy closure is important to understand and to describe the transition dynamics occurring; since, through photointerpretation of the available images, it was possible to discriminate the different crown cover density, in some cases a fourth digit (level) was introduced to describe the texture of forest trees coverage.

A simplified LULC map has been obtained by merging the original CLC categories into six larger groups, or macroclasses, which are representative of the main transformations observable in the detailed transition matrix: Artificial surfaces (AS), Arable lands $(\mathrm{AL})$, Grassland (GR), Forest (FO), Shrubs and herbaceous plants (SH) and Bare rock (BR) (Figure 4). 
Table 2. Land cover classes for the study area in 2016.

\begin{tabular}{|c|c|}
\hline CLC Code & Land Cover Class \\
\hline 1 & Artificial surface \\
\hline 21 & Arable lands \\
\hline $311-\mathrm{a}$ & Structured deciduous forests \\
\hline $311-b$ & Compact deciduous forests with fine texture \\
\hline $311-\mathrm{c}$ & Open deciduous forests with rare or none undergrowth \\
\hline $312-\mathrm{a}$ & Coniferous tree planting \\
\hline $312-b$ & Closed coniferous forests \\
\hline $312-c$ & Open coniferous forests \\
\hline $321-\mathrm{a}$ & Meadows of the sinkholes on red earth and nardus grasslands \\
\hline $321-b$ & Mesophilic and xerophilic grasslands \\
\hline $321-\mathrm{c}$ & Grasslands with prostrate shrubs and scattered trees \\
\hline $321-\mathrm{d}$ & Grasslands with tall shrubs and scattered trees \\
\hline $322-\mathrm{a}$ & Prostrate shrubs \\
\hline $322-b$ & Tall shrubs, arboreal-shrub colonization formations \\
\hline $324-\mathrm{a}$ & Sparse deciduous forests \\
\hline $324-b$ & Very sparse broad-leaved forests with mainly herbaceous formations \\
\hline $324-\mathrm{c}$ & Very sparse broad-leaved forests with mainly shrub formations \\
\hline 324-dc & Sparse coniferous forests \\
\hline 332 & Bare rock \\
\hline 333 & Sparsely vegetated areas \\
\hline
\end{tabular}

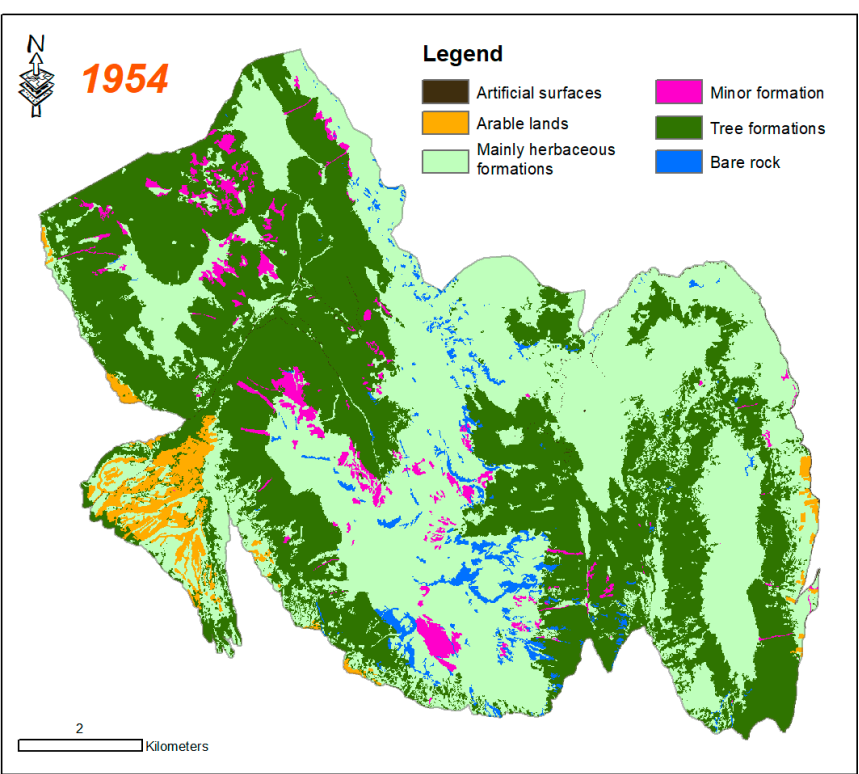

(a)

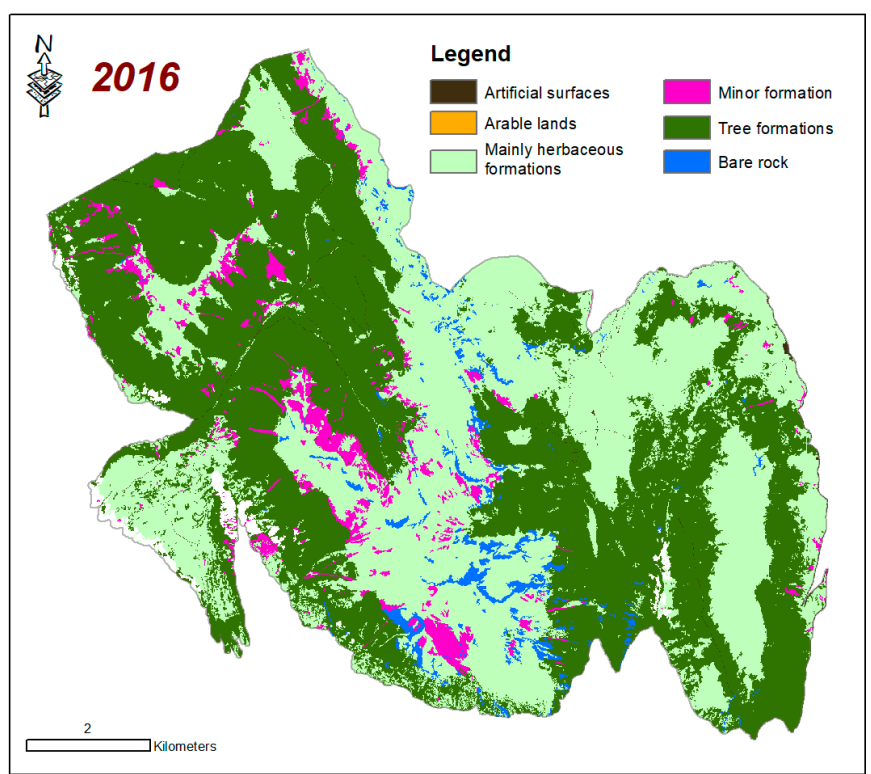

(b)

Figure 4. Grouped Land Use/Land Cover Maps for (a) 1954 and (b) 2016.

The cross-tabulation matrix (transition matrix) was computed using overlay functions in ArcGIS software to analyze Land Cover transitions. Analysis of gains, losses, persistence and net change were carried out for the period: 1954-2016. The computed transition matrix consists of rows that display categories at time 1 and columns that display categories 
at time 2. The diagonal elements indicate the proportion of the landscape that shows persistence of the category, while elements off the diagonal indicate a transition from a category to a different one. The land-cover changes (LULCC) for the 1954-2016 period have been assessed both for the detailed LULC maps (Figure 5) and for the simplified LULC maps (Table 3). The gains were calculated as the differences between the column totals and persistence, while losses were calculated as the differences between the raw totals and persistence. The total change has been calculated as the sum of gains and losses and represents the total surface showing a variation in both directions; on the contrary, the net change, calculated as the difference between gains and losses, represents the real variation of each class. The net change does not consider the simultaneous increase and decrease occurring for a land cover class; this phenomenon, defined as "swap" by some authors, can be calculated as the difference between total change and net change. The propension of land cover classes to transition were assessed by calculating the loss-to-persistence ratio denoted by Lp and the gain-to-persistence ratio denoted by Gp. Higher tendency of land cover transition to other categories that persist is expressed by values of Lp and Gp greater than one [49]. The overall propension to change, $\mathrm{Cp}$, was evaluated calculating the net change to persistence ratio; it expresses the net increase or decrease of a class compared with persistence, and higher values reflect an attitude to changes.

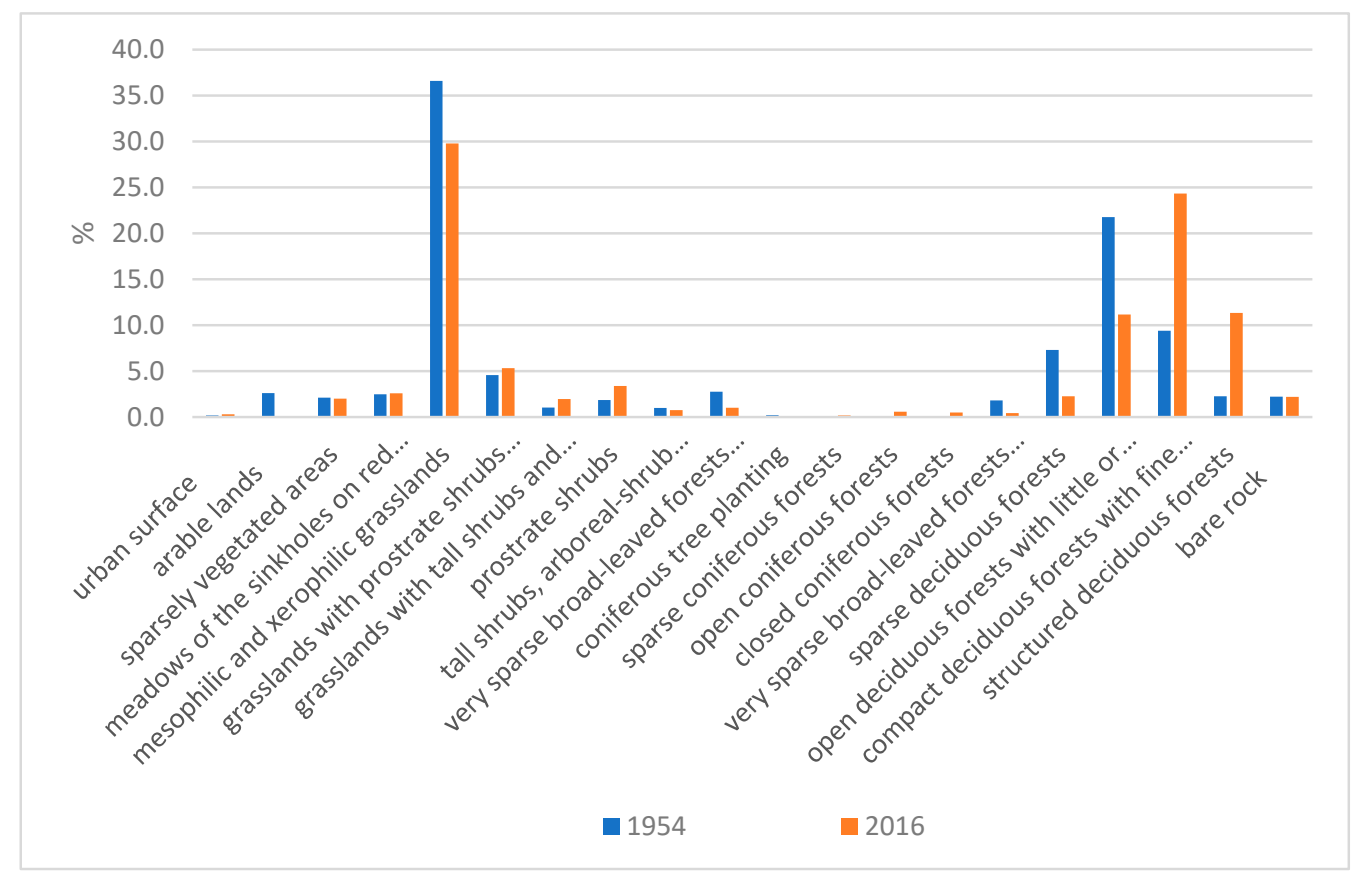

Figure 5. Percentage of variation of LULC classes in 1954-2016.

As a consequence of the abandonment of mountain areas and the decrease of anthropic pressure, the restoration of natural uncultivated state is ongoing. In order to point out this phenomenon, the LULC types have been ordered according to a degree of naturalness, assigning a score ranging from 1 (low naturalness) to 16 (high naturalness) and a value of 17 to non-vegetated areas. (Table 4). According to this order, when an area has changed its land use between 1954 and 2016, its score of naturalness (named Naturalization Index NI) can be increased or reduced. In the context of conservation biology, the term "natural" is used to define anything that has not been made or influenced by humans, particularly by technology. If we accept "natural" as being the antonym of "artificial", the "naturalness" or the quality of being natural would express the level at which something occurs without artificial influence, a gradient ranking from the extreme of absolutely natural to the opposite, absolutely artificial. This conceptual approach is not free from debate, affecting both the role of humans in the ecosystem, as well as the time span of its influence [50]. 
Table 3. Transition matrix for macroclasses of land cover (Total change $=$ Gains + Losses; Net change $=$ Gains-Losses; Swap = Total Change-Net Change; Lp = Losses /Persistence; Gp = Gains/Persistence; $\mathrm{Cp}=$ Net Change/Persistence).

\begin{tabular}{|c|c|c|c|c|c|c|c|c|c|c|c|c|c|c|}
\hline $\begin{array}{l}2016 \\
1954\end{array}$ & BR & AL & FO & SH & GR & AS & $\begin{array}{c}1954 \\
\text { TOTAL }\end{array}$ & LOSSES & $\begin{array}{l}\text { Total } \\
\text { Change }\end{array}$ & $\begin{array}{l}\text { Net } \\
\text { Change }\end{array}$ & Swap & Lp & $\mathrm{Gp}$ & $\begin{array}{l}\text { Change } \\
\text { Propension }\end{array}$ \\
\hline $\mathrm{BR}$ & 1.799 & 0.000 & 0.005 & 0.003 & 0.023 & 0.000 & 1.830 & 0.031 & 0.048 & -0.014 & 0.034 & 0.017 & 0.009 & 0.000 \\
\hline $\mathrm{AL}$ & 0.000 & 0.000 & 0.275 & 0.066 & 1.802 & 0.017 & 2.160 & 2.160 & 2.160 & -2.160 & 0.000 & - & - & - \\
\hline FO & 0.004 & 0.000 & 37.199 & 0.146 & 0.269 & 0.030 & 37.647 & 0.448 & 6.118 & 5.222 & 0.896 & 0.012 & 0.152 & 0.002 \\
\hline $\mathrm{SH}$ & 0.000 & 0.000 & 0.732 & 1.476 & 0.126 & 0.001 & 2.334 & 0.858 & 2.797 & 1.081 & 1.717 & 0.582 & 1.314 & 0.019 \\
\hline GR & 0.013 & 0.000 & 4.652 & 1.723 & 32.258 & 0.078 & 38.724 & 6.467 & 8.692 & -4.241 & 4.450 & 0.200 & 0.069 & 0.003 \\
\hline AS & 0.000 & 0.000 & 0.006 & 0.002 & 0.005 & 0.123 & 0.136 & 0.013 & 0.139 & 0.113 & 0.026 & 0.104 & 1.024 & 0.011 \\
\hline $\begin{array}{c}2016 \\
\text { TOTAL }\end{array}$ & 1.816 & 0.000 & 42.869 & 3.415 & 34.483 & 0.249 & 82.831 & 9.977 & 19.953 & & & & & \\
\hline GAINS & 0.017 & 0.000 & 5.670 & 1.939 & 2.225 & 0.126 & 9.977 & & & & & & & \\
\hline
\end{tabular}

Table 4. Naturalness score of the different LULC classes.

\begin{tabular}{|c|c|}
\hline Naturalness & Cover Class \\
\hline 1 & urban surface \\
\hline 2 & arable lands \\
\hline 3 & sparsely vegetated areas \\
\hline 4 & meadows of the sinkholes on red earth and nardus grasslands \\
\hline 4 & mesophilic and xerophilic grasslands \\
\hline 5 & grasslands with prostrate shrubs and scattered trees \\
\hline 5 & grasslands with tall shrubs and scattered trees \\
\hline 6 & prostrate shrubs \\
\hline 6 & tall shrubs, arboreal-shrub colonization formations \\
\hline 7 & very sparse broad-leaved forests with mainly herbaceous formations \\
\hline 8 & coniferous plants \\
\hline 9 & sparse coniferous forests \\
\hline 10 & open coniferous forests \\
\hline 11 & closed coniferous forests \\
\hline 12 & very sparse broad-leaved forests with mainly shrub formations \\
\hline 13 & sparse deciduous forests \\
\hline 14 & open deciduous forests with little or no undergrowth \\
\hline 15 & compact deciduous forests with fine texture \\
\hline 16 & structured deciduous forests \\
\hline 17 & Bare rock \\
\hline
\end{tabular}

The score has been attributed by an expert group; according to this order, LULC changes which occurred in an area between 1954 and 2016 can imply an increase or a reduction of naturalness. A diachronic analysis of NI values allows to obtain an evolution map of the renaturalization degree and allows the implementation of a raster map describing the trend of the rewilding (Renaturalization dynamic map, Figure 6). 


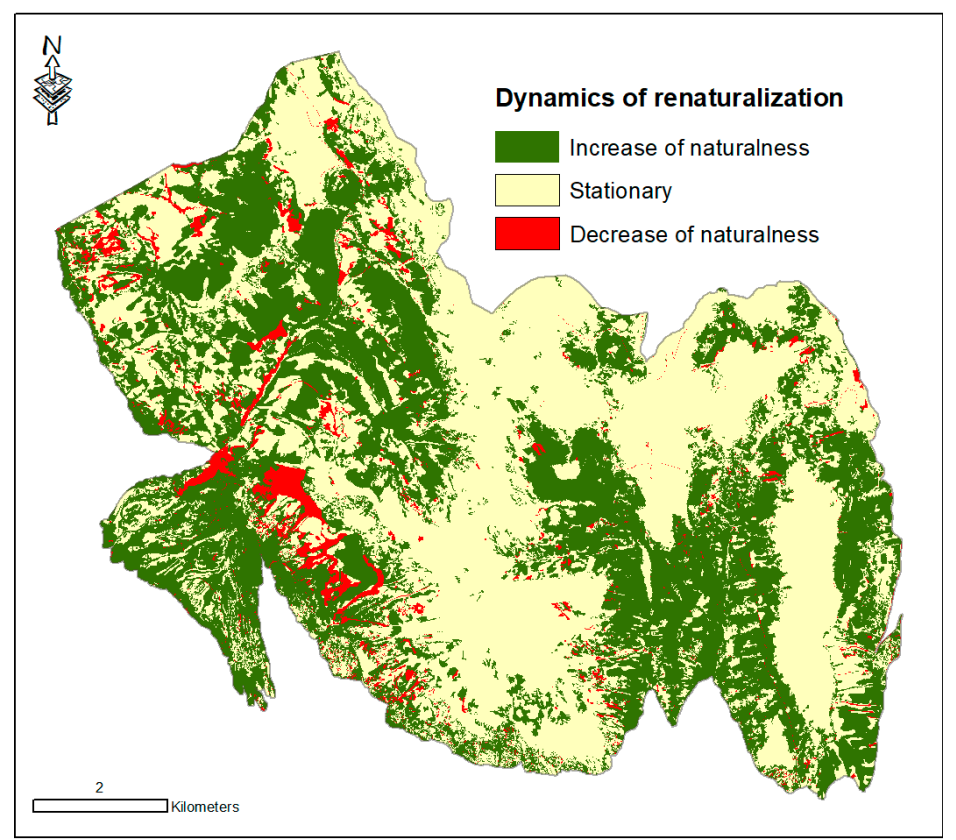

Figure 6. Dynamic of Renaturalization in the period 1954-2016.

An analysis of the density of forest cover has been performed in order to highlight the increase or the reduction of forest density and to identify the transition areas where the closure of clearings is occurring (Figure 7, Clearings evolution map).

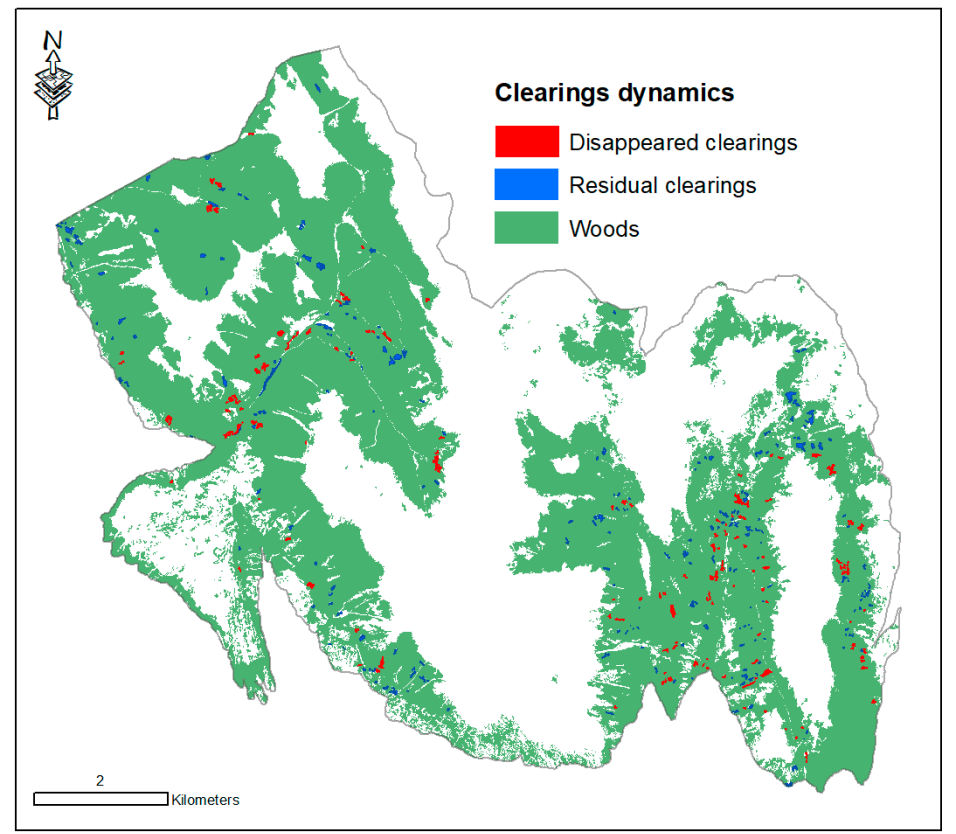

Figure 7. Clearings dynamics in the period 1954-2016.

\section{Results}

On the basis of the LULC maps obtained for the years 1954 and 2016 (see Appendix A, Figure A1), the variation for each of the twenty LULC classes identified was calculated and is summarized in Table A1 (see Appendix A) and shown in Figure 5.

In the study area covering $82.83 \mathrm{~km}^{2}$ above $1300 \mathrm{~m}$ asl, the reduction of the Xerophilic mesophilic grassland is considerable $(18 \%)$, although it remains the most widespread LULC, covering about $30 \%$ of the whole area. A relevant increase in the class "Compact deciduous forests with fine texture", that has almost tripled its surface, is observed, and 
in 2016 they represented $24 \%$ of the study area. Additionally, high is the variation of the class "Structured deciduous forests" which increases from $2 \%$ up to $11 \%$ of the total area. A reduction of "open deciduous forest" can be observed, which now, overall, has reached $11 \%$, being equal to $22 \%$ of the study area in 1954 . The marginal agricultural fields cultivated with cereals or mountain legumes, which represented $2.6 \%$ of the surface in 1954, have completely disappeared. The transition matrix among the 20 classes (see Appendix A, Table A2) provides the direction of transformation which occurred and highlights the intense and relevant process of the increase of the crown cover density.

In order to highlight the main trends of transformations, a transition matrix analyzing the six macroclasses has been produced (Table 4).

The transition matrix of macroclasses highlights a relevant increase of Forests (Net change of $5.22 \mathrm{~km}^{2}$ ) mainly to the detriment of Grassland and to a lesser extent of Shrubs; also, the class Shrubs shows a net change of $1.08 \mathrm{~km}^{2}$, mainly deriving from a loss of Grassland. A transition from Shrubs to Forest can be observed too, while the class Arable land is almost totally turned into Grassland. Considering the Swap values, Grassland are the most dynamic class with the highest surface subject to changes both in terms of acquisition (essentially from Arable land) and in terms of substitution towards Shrubs and Forests. Moreover, the class Shrub is strongly dynamic, showing a transition to Forests and a contemporary noticeable acquisition from Grassland. Considering Lp, Gp and Cp, the class Shrubs show the most relevant dynamic and show the greatest attitude to change and, specifically, to increase its surface, being $\mathrm{Gp}>1$.

The rate of transitions, calculated simply as the ratio of the net change to the time interval, points out a relevant annual average change for the classes Forests, Shrubs and Grassland. The classes "Structured deciduous forests" and "Compact deciduous forests with fine texture" show, respectively, an increase of the mean annual area of 12 and 19 ha $^{-1}$, that is lower than the values described in other studies carried on in the Apennines [11] (Table A1). Analyzing the dynamics of forests' structures, an evident trend to the closure of forests is highlighted by an increase of compact structures and a decrease of open and sparse formations. These results clearly show the reduction of the anthropic pressure, the transition from Grassland and herbaceous formations towards Forest systems and the triggering of an ecological succession. In order to describe the dynamics of renaturalization, the difference between the NI scores of 1954 and the NI scores of 2016 on the basis of the detailed LULC maps with 20 classes has been calculated as a raster map (Evolution of naturalness map, Figure A2). The map represents, for each pixel, the extent of the process in terms of the number of jumps in the hierarchical scale of naturalness. For example, a pixel with a value of 6 must be interpreted as a transformation of the historical land use that has 6 steps forward in the 17-step staircase (e.g., a meadow that becomes very sparse wood). In the map, negative values indicate a renaturalization process while positive ones denote the opposite process. Starting from the "Evolution of naturalness" map, a synthesis map with three classes showing increase, decrease or stationarity of the degree of naturalness, has been derived. The dynamic of the Naturalization Index calculated and compared for the two periods, confirms these findings, highlighting a diffuse renaturalization in these areas (Figure 6).

As previously stated, the renaturalization processes determine an increase in trees coverage and in the degree of canopy closure; hence, a focus on the dynamics of clearings and on the transition from this important class of LULC has been carried out.

The total area of the clearings in 1954 amounted to $0.84 \mathrm{~km}^{2}$, while in 2016 the total area of this class was reduced to $0.296 \mathrm{~km}^{2}$ (Table 5). Sixty-five percent of the initial area evolved into other LULC types; the most significant transitions were towards the classes of deciduous forests, both open and compact with fine texture. The clearings in a number of 335 in 1954 have undergone a decrease and the 198 remaining generally show a reduction in size. 
Table 5. Trajectories of evolution of clearings in the period 1954-2016.

\begin{tabular}{|c|c|c|}
\hline Land Cover Class & $\begin{array}{c}\text { Surface } \\
\left(\mathrm{ha}=\mathrm{km}^{2} \times 100\right)\end{array}$ & Surface $(\%)$ \\
\hline Artificial surface & 0.21 & 0.25 \\
\hline Structured deciduous forests & 5.15 & 6.13 \\
\hline Compact deciduous forests with fine texture & 16.00 & 19.05 \\
\hline Open deciduous forests with little or no undergrowth & 19.66 & 23.41 \\
\hline Sparse deciduous forests & 4.98 & 5.93 \\
\hline Very sparse broad-leaved forests with mainly herbaceous formations & 1.67 & 1.99 \\
\hline Very sparse broad-leaved forests with mainly shrub formations & 1.70 & 2.02 \\
\hline Closed coniferous forests & 0.20 & 0.23 \\
\hline Open coniferous forests & 0.58 & 0.69 \\
\hline Sparse coniferous forests & 0.88 & 1.04 \\
\hline Prostrate shrubs & 1.92 & 2.29 \\
\hline Tall shrubs, arboreal-shrub colonization formations & 1.41 & 1.68 \\
\hline Persistent Clearings 2016 & 29.63 & 35.28 \\
\hline TOTAL Clearings 1954 & 83.98 & 100.00 \\
\hline
\end{tabular}

\section{Discussion}

In the study area, the landscape has evolved so as to show a general advancement of forests and a colonization of open areas by shrubs; at the same time a reduction of grasslands can be observed. This dynamic confirms the previous results of other studies on other Mediterranean mountains, although this study is focused on higher elevation (>1300 m); it describes a decline of grasslands, shrublands and croplands in mountain regions, and the reforestation process observed by other authors [11,12,37]. Focusing on forests, the dynamism of their structure deducible from the transition matrix calculated on the detailed LULC map is very interesting. Unlike other studies, the use of photointerpretation, although very time-consuming, allows to analyze the degree of crown cover density and to monitor the canopy closure processes that are ongoing. In addition to the net increase in surfaces, the transition matrix highlights a gradual replacement of shrubs and sparse woods by denser formations with an increase in the degree of the canopy coverage. The rate of forest expansion, calculated for the two classes "Compact deciduous forest" and "Structured deciduous forest" is lower than in other similar studies carried out in the Apennines; furthermore, large areas of shrub are still observed. Further studies and the analysis of intermediate periods are needed to determine the beginning of the transition. Nevertheless, it would seem that the process of canopy closure is slower than others described by other authors [12] and requires more than 25 years to be completed.

This behavior involves the dynamics of the clearings within the forests which have reduced both in number and in size, in the period 1954-2016. As a consequence, a gradual simplification of the landscape pattern is occurring and it determines a reduction of heterogeneity and biodiversity.

The "Naturalization Index", attributed by an expert group, highlighted an overall reduction of the anthropic pressure as a consequence of natural processes triggered by the cessation of grazing. The abandonment of the territory, of agricultural activities and of pastoralism, in fact, promotes the renaturalization processes witnessed by the ongoing transitions and by the contemporary loss of the traditional landscape shape.

The main driving forces for this phenomenon can be identified in the depopulation and the subsequent cessation of traditional pastoral activities, together with the long-term changes in forest management and harvesting, related to the rules and the management of the protected area. 
Going back to 1954, the landscape was characterized by a more articulated mosaic where the anthropic activity was also part of the system, while the present landscape certainly appears less diversified and heterogeneous. In a few decades, the reduction in human activity has led to a considerable modification of the landscape that has been also altered by the recolonization of the arboreal and shrubby formations replacing the open habitats.

The generalized process of woody encroachment is a controversial topic among ecologists, engineers, geographers and other scientists and the debate about the consequences on biodiversity and ecosystem services of rewilding driven by land abandonment is still ongoing. There is no clear consensus regarding the best way to improve the ecological relationships and functioning within an ecosystem [51]. On the one hand, the abandonment can provide a unique opportunity for regenerating native ecosystems with high nature values, such as native forest, or restoration of natural grasslands; on the other hand, the widespread abandonment of agricultural or pastoral practices in some areas increases landscape homogenization, which leads to biodiversity declines [52]. Furthermore, the proliferation of pioneer species and reduced functional diversity have the potential to disrupt some trophic interactions and lead to a future biodiversity loss [53].

To this it must be added the loss of "cultural" diversity represented by the disappearance of traditional landscapes that enclose the identity values of the territory and represent an important legacy for local communities [54].

If a general consensus exists around the need for biodiversity conservation, broadening the concept of diversity to encompass more than biological diversity, appears more controversial. The difficulties in combining landscape diversity with cultural diversity, probably lie in the differences in meaning of the word "landscape" in different tongues. It implies differences linked to local customs, laws and social structures and also to memories and beliefs [55-57].

The debate is heated around this issue involving ecologists, engineers, geographers and other scientists. Some authors emphasize the importance of biological diversity [58], while, according to other authors, equal importance must be given to the conservation of the diversity of cultural landscapes [59,60]. According to some authors [61], places inhabited by humans for millennia biodiversity and human activities have coevolved, producing ecologically valuable cultural semi-natural landscapes that can be threatened by depopulation.

These critical questions have not been definitively addressed to date, largely due to the complexity of the ecological, geographical, social and economic factors that contribute to management decisions regarding mountain areas [51].

The disappearance of low income activities, the difficulties associated with carrying out these activities and in general, the change in socioeconomic conditions are at the base of the abandonment and of the resulting landscape transformation.

These transformation trajectories are quite widespread in the mountain areas of several EU countries and they do not seem to be arrested without specific policies and interventions [62-64].

Forests have spread throughout the French Mediterranean hills and mountains which have now become some of the most afforested regions in France. The eastern French Pyrenees has recently been affected by dramatic land abandonment and various afforestation dynamics [65]).

The Urbión Mountains (Iberian Range, northern Spain) provides one of the clearest examples in the Iberian Peninsula, where there was intense deforestation since the Neolithic period to enlarge the area of subalpine summer grasslands. The recent reversal of this situation in the last decades led to (i) a marked trend to dense forest, which resulted in an average $200 \mathrm{~m}$ altitudinal advance, and (ii) the spatial contraction of shrublands, which have been replaced by dense forest in the highest areas [66]. In Germany, the abandonment of agriculture on marginal locations in favor of afforestation will considerably change the appearance of highly diverse cultural landscapes [67] under the given economic constraints 
for farming and inadequate governance. The authors call for future studies aimed at assessing the value added of maintaining agriculture on marginal land instead of forest; the comparison of the potential beneficial or negative impacts on ecosystem service supply and demand could help to evaluate thresholds for the share and intensity of agriculture that considerably improve or deteriorate regulating and cultural ecosystem services as well as biodiversity.

According to many authors, the maintenance of landscapes with high habitat diversity needs agricultural policies specifically favoring a mosaic of arable land, grassland, and fallow land habitats. Therefore, sufficiently endowed agri-environmental schemes offered in Pillar Two of the CAP are highly important [68].

The possible solution to reverse the abandonment trend and favor the maintenance of traditional activities and cultural landscapes seems to be the introduction of direct payments or other incentivization schemes aimed at actively keeping the clearings open, and at contrasting the advancement and closure of the forests with the reintroduction of grazing [68-70].

The recognition of the differences between territories is fundamental to design policies directed specifically at alleviating the problems associated with undesirable abandonment where relevant, while addressing other objectives in other areas. The diverse nature of farming and natural conditions throughout Europe requires a more territorial and spatial approach to dealing with land abandonment to ensure that the rules governing agricultural subsidies can reach the desired outcomes [63,71].

A crucial role can be played by Protected Areas, although often the management of these areas is effective for the conservation of species and ecosystems, but not as effective for stopping depopulation rates despite the development opportunities offered by tourism activities. In Spain, for example, some socioeconomic funding programs have been put in place nationally (Spanish government, 2005) and regionally (e.g., Government of Castilla y Leon, 2017; Government of Galicia, 2018; Government of Cantabria, 2019). Such programs can finance initiatives by public entities, businesses, individuals, or NGOs that are aimed at promoting rural development and sustainable tourism, enhancing local services and facilities and rehabilitating cultural heritage [72].

In the studied area, the presence of the SCI/SPA-Abruzzo National Park provides a precise indication for the management of these areas. The presence of the habitat 6210-Semi-natural dry grasslands and scrubland facies on calcareous substrates (FestucoBrometalia) imposes different operational strategies, as stated in the Technical Report on Natura 2000 of EC. Scrub invasion is considered to be an acute threat for this habitat because it can result in an increase in soil nutrients and a decline of richness in grassland species. It is not, therefore, advocated that scrub should be allowed to colonize at the expense of existing semi-natural grassland of high nature conservation value.

In the SCI management plan, the main threat for this habitat is precisely identified in the abandonment of pasture and the consequent advancement of the forest; the specific interventions required for the maintenance of this habitat are exactly the reintroduction of pasture. In this direction can be cited the LIFE-Project GRACE (GRAsslands Conservation Efforts through usage) whose main objective is to promote the conservation of semi-natural habitats by supporting their use; among the others goals, the project aims at the integration of Green Public Procurement (GPP) in involving local territorial bodies in actions to enhance grazing and in the conservation objectives of the N2000 network.

An active management of abandoned land requires planning and investment for the maintenance of traditional activities; private landowner involvement and public support is crucial for both funding and the long-term maintenance of benefits.

In the last decade, the Italian government has sought to reverse the depopulation and marginalization of rural areas by promoting strategies for reducing hydrogeological instability and triggering development. These measures are grouped under the overall "Strategy for Internal Areas" that classifies each Italian municipality into one of the six categories (from central to ultraperipheral) depending on the distance (in time) to basic 
services, including hospitals, regional railway stations, and schools [73]. The strategy provides investments of over $€ 591$ million and aims at slowing and reversing depopulation of inner areas, improving essential services and guaranteeing local communities new opportunities for life and development. In fact, the possibility of setting up new economic activities and the creation of employment is closely related to the enhancement of the qualitative and quantitative offer of essential services

\section{Conclusions}

The aim of this study is to describe the landscape changes which occurred in an area situated above $1300 \mathrm{~m}$ asl of PNALM (Central Apennines, Italy), between 1954 and 2016 by using past and recent aerial photos. Data on land use/land cover classes were analyzed by means of transition matrix.

Overall, we observed a large change in landscape composition and configuration, regarding about $50 \%$ of the investigated area, which denotes an intense evolutive trend of this territory. The rate of the LULC change in the Apennines context, at an elevation above $1300 \mathrm{~m}$, seems to be not exactly in compliance with the results of the recent study [11] that, in a comparison between the Alps and Apennines context, concluded that, "However, the rate of forest expansion was faster in the Apennines for the larger occurrence at lower elevations of old-fields recolonized by secondary forests. In the Alps, climate and land use changes favored a widespread transition from unvegetated areas to forest at higher elevations".

All open habitats, such as grasslands, declined, while woodlands expanded through spontaneous reforestation, at the expense of open lands. This finding confirms the general trend of landscape changes, also observed at a larger scale in rural and mountain areas in Italy and in other European countries $[11,12,30,74]$. In the studied area, the relative proportion of LULC classes and the annual transition matrix showed that pastures and open areas were replaced by woodlands, but the transition appears slower than the 25 years described by other authors [12].

Rewilding, defined [30,75], as «the passive management of ecological succession with the goal of reducing human control and restoring natural ecosystem processes» favors the expansion of forests even if their structure is strongly influenced by previous management [76]. The abandonment of pastures and traditional activities entails the loss of biodiversity, cultural diversity and landscape heterogeneity, an important legacy for local communities.

"Landscape" means an area, as perceived by people, whose character is the result of the action and interaction of natural and/or human factors (European Landscape Convention, ELC); many traditional landscapes are man-shaped without any aesthetic or ecological purpose. A number of policies, laws and, in some cases, financial tools addressed to the conservation of biodiversity and, more in general, of natural heritage already exist. As for the landscape, although the ELC is aimed at preserving landscape quality, specific policies and financial intervention addressed towards rural landscape conservation are lacking. These transformation trajectories do not seem to be arrested by actively keeping the clearings open, and by contrasting the advancement and closure of the forests through direct interventions or with the reintroduction of grazing.

From these considerations, three major questions arise: What can be done to cultural landscapes that tend to be rapidly recovered with shrubs and forests? Is farmland and grazing abandonment the best option for improving biodiversity and sustainability, and for enhancing refaunation? Or is it preferable to actively manage the landscapes in order to enhance their natural heterogeneity with the presence of light human activity [51]?

A further question arises about the role of the protected areas: must they pursue the purposes of conservation of natural environments favoring the rewilding and renaturalization, or must they protect also cultural values?

It must be kept in mind that only specific planned intervention or subsidies can allow these typical landscapes to survive. 
In the present paper, the use of aerial photos and photointerpretation, although challenging and time-consuming, provide more detailed information than other methodologies and also allow to identify the densification of the canopy coverage. Although the general transformation processes are well known, a deep knowledge of the territory is essential for a correct and effective allocation of financial resources. In this perspective, it is necessary not only to identify the phenomenon, but also to carry out an accurate monitoring of the territory; the present study can provide a contribution to understand and map the dynamics that are occurring and to improve the management and planning in these areas which are widely replicable to similar contexts.

Author Contributions: Conceptualization, M.N.R. and L.B.; methodology, C.M.R.; investigation, E.P.; data curation, C.M.R. and E.P.; writing-original draft preparation, M.N.R. and L.B.; writingreview and editing, M.N.R. and L.B. All authors have read and agreed to the published version of the manuscript.

Funding: This research received no external funding.

Institutional Review Board Statement: Not applicable.

Informed Consent Statement: Not applicable.

Data Availability Statement: Data produced in this study are is contained within the same article or within the Appendix A. Historical photographs was obtained by IGMI (Italian Geographic Military Institute). Their use is subject to restrictions and the authors are not enabled to share them. 2016 Images are extracted from Google Earth.

Acknowledgments: The research was carried out in the frame of the MIUR (Ministry for Education, University and Research) initiative "Department of excellence" (Law 232/2016).

Conflicts of Interest: The authors declare no conflict of interest.

\section{Appendix A}

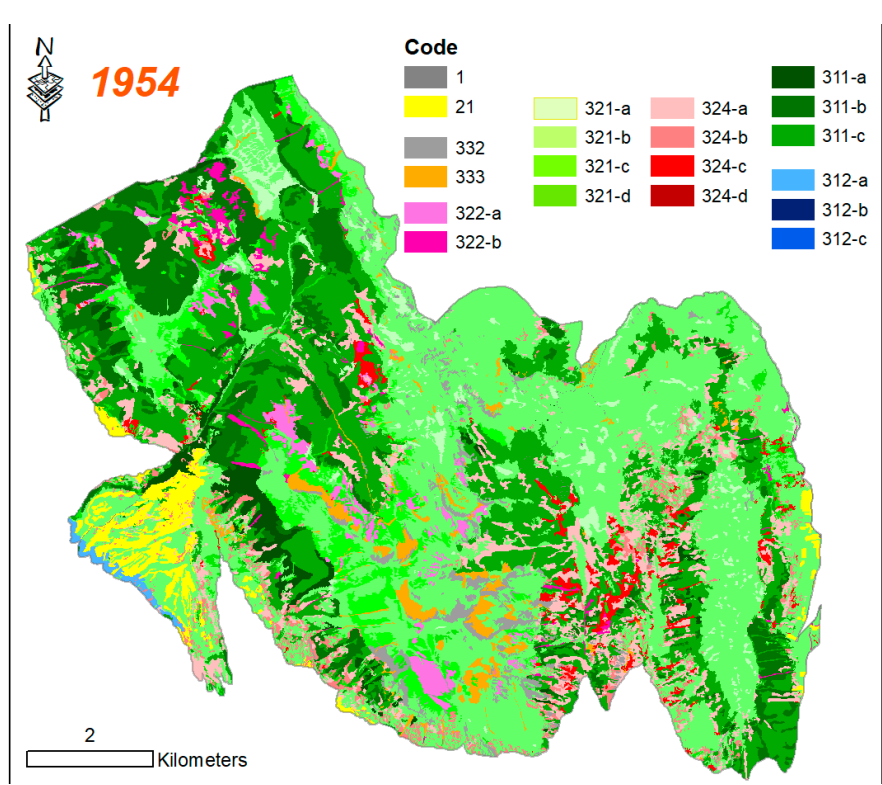

(a)

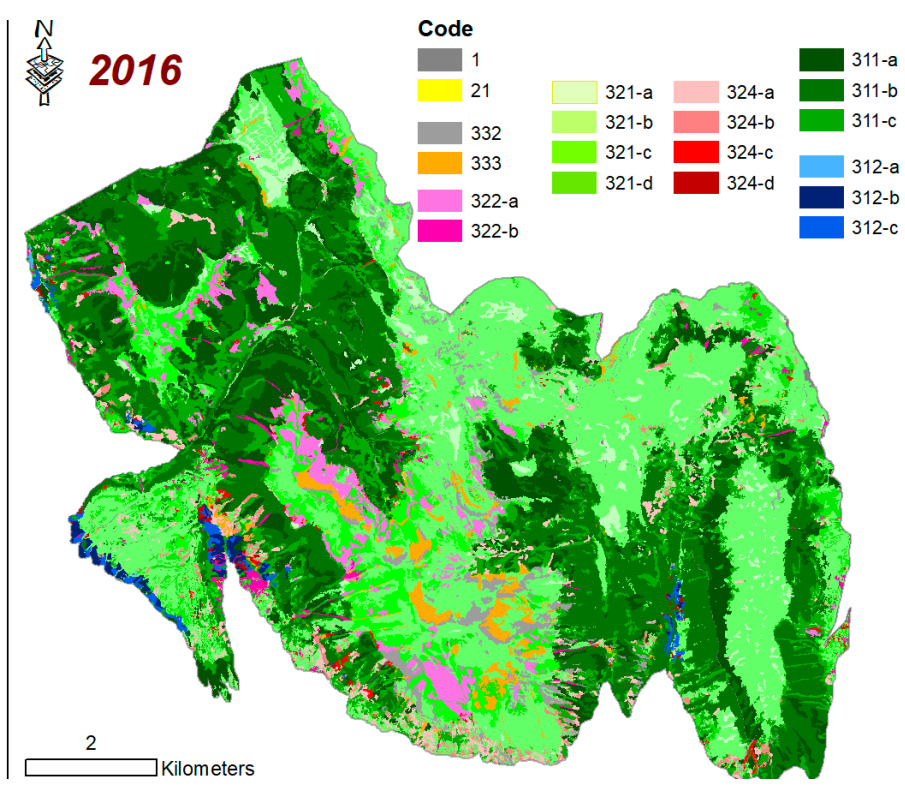

(b)

Figure A1. Land cover maps (a) 1954 and (b) 2016 in 20 classes of LULC. 


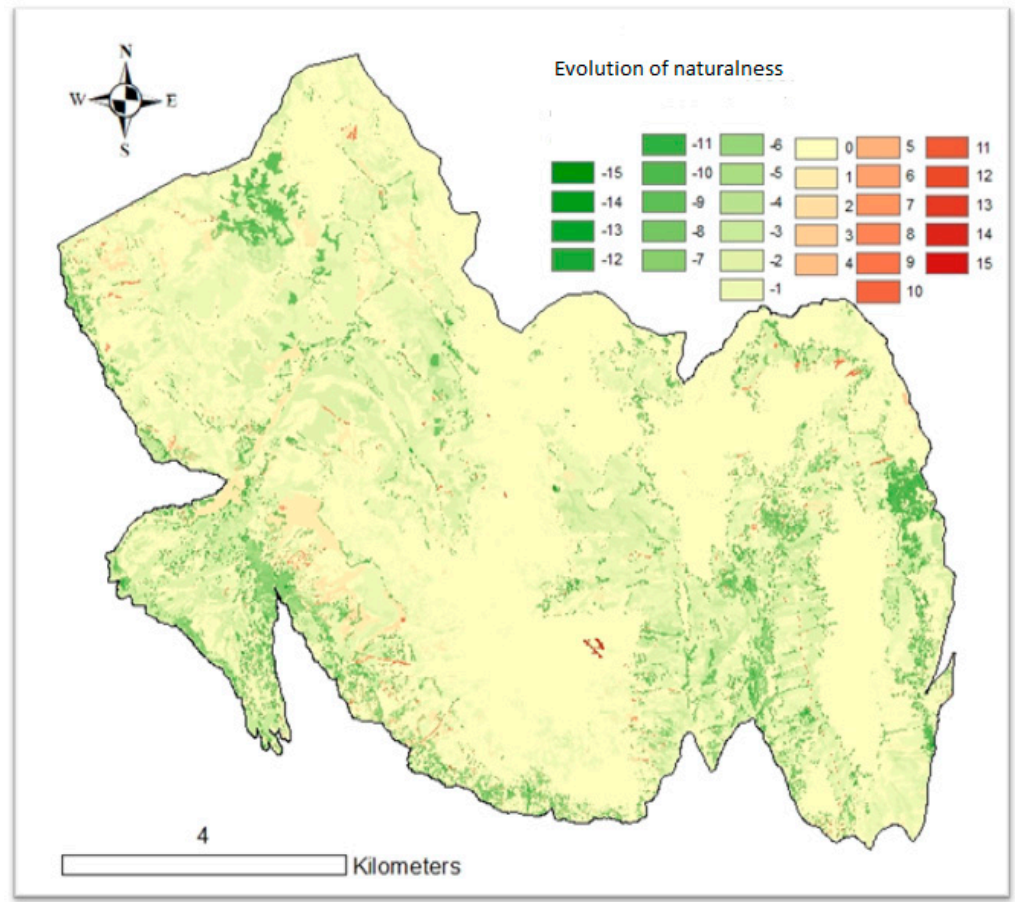

Figure A2. Evolution of naturalness in the period 1954-2016. 
Table A1. Surfaces, variations and rate of variation for the identified classes of land use in the period 1954-2016.

\begin{tabular}{|c|c|c|c|c|c|c|c|c|}
\hline CLC & LAND COVER & AREA 1954 (ha) & $\begin{array}{c}\text { AREA } 2016 \\
\text { (ha) }\end{array}$ & AREA 1954 (\%) & AREA $2016(\%)$ & Variation (ha) & Variation (\%) & Rate \\
\hline 1 & Artificial surface & 13.56 & 24.86 & 0.16 & 0.30 & 11.30 & 83.33 & 0.18 \\
\hline 21 & Arable lands & 215.99 & 0.00 & 2.61 & 0.00 & -215.99 & -100.00 & -3.48 \\
\hline 311-b & Compact deciduous forests with fine texture & 778.17 & 2015.00 & 9.39 & 24.33 & 1236.83 & 158.94 & 19.95 \\
\hline $311-\mathrm{c}$ & Open deciduous forests with rare or none undergrowth & 1802.82 & 924.91 & 21.76 & 11.17 & -877.92 & -48.70 & -14.16 \\
\hline $312-\mathrm{a}$ & Coniferous plantations & 15.41 & 1.53 & 0.19 & 0.02 & -13.88 & -90.09 & -0.22 \\
\hline $312-\mathrm{c}$ & Open coniferous forests & 0.00 & 47.44 & 0.00 & 0.57 & 47.44 & - & 0.77 \\
\hline $321-\mathrm{a}$ & Meadows of the sinkholes on red earth and nardus grasslands & 203.85 & 213.89 & 2.46 & 2.58 & 10.04 & 4.92 & 0.16 \\
\hline $321-\mathrm{b}$ & Mesophilic and xerophilic grasslands & 3030.70 & 2467.48 & 36.59 & 29.79 & -563.22 & -18.58 & -9.08 \\
\hline $321-\mathrm{c}$ & Grasslands with prostrate shrubs and scattered trees & 378.53 & 440.15 & 4.57 & 5.31 & 61.62 & 16.28 & 0.99 \\
\hline $321-\mathrm{d}$ & Grasslands with tall shrubs and scattered trees & 84.75 & 161.21 & 1.02 & 1.95 & 76.45 & 90.21 & 1.23 \\
\hline $322-\mathrm{a}$ & Prostrate shrubs & 152.27 & 279.70 & 1.84 & 3.38 & 127.43 & 83.68 & 2.06 \\
\hline $322-b$ & Tall shrubs, arboreal-shrub colonization formations & 81.16 & 61.79 & 0.98 & 0.75 & -19.37 & -23.87 & -0.31 \\
\hline $324-b$ & Very sparse broad-leaved forests with mainly herbaceous formations & 227.34 & 82.93 & 2.74 & 1.00 & -144.41 & -63.52 & -2.33 \\
\hline $324-\mathrm{c}$ & Very sparse broad-leaved forests with mainly shrub formations & 149.21 & 35.71 & 1.80 & 0.43 & -113.50 & -76.07 & -1.83 \\
\hline $324-\mathrm{d}$ & Sparse coniferous forests & 0.00 & 12.76 & 0.00 & 0.15 & 12.76 & - & 0.21 \\
\hline 332 & Bare rock & 183.02 & 181.59 & 2.21 & 2.19 & -1.43 & -0.78 & -0.02 \\
\hline 333 & Sparsely vegetated areas & 174.60 & 165.59 & 2.11 & 2.00 & -9.01 & -5.16 & - \\
\hline
\end{tabular}


Table A2. Transition Matrix among the 20 classes of LULC.

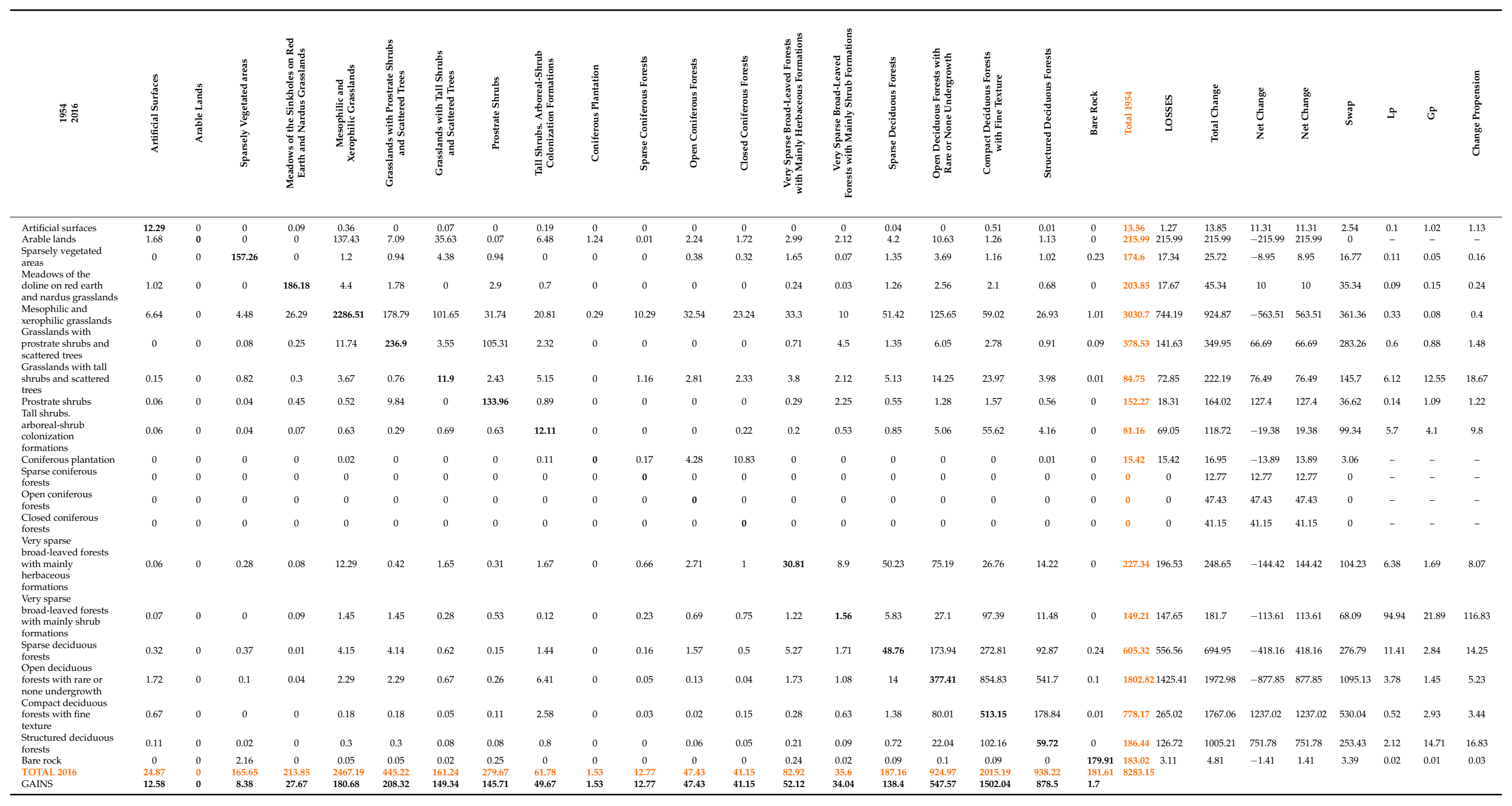




\section{References}

1. Forman, R.T.T.; Godron, M. Landscape Ecology; John Wiley and Sons Ltd.: New York, NY, USA, 1986.

2. Antrop, M. Background concepts for integrated landscape analysis. Agric. Ecosyst. Environ. 2000, 77, 17-28. [CrossRef]

3. Turner, M.G.; Donato, D.C.; Romme, W.H. Consequences of spatial heterogeneity for ecosystem services in changing forest landscapes: Priorities for future research. Landsc. Ecol. 2012, 28, 1081-1097. [CrossRef]

4. Campagnaro, T.; Frate, L.; Carranza, M.L.; Sitzia, T. Multi-scale analysis of alpine landscapes with different intensities of abandonment reveals similar spatial pattern changes: Implications for habitat conservation. Ecol. Indic. 2017, 74, 147-159. [CrossRef]

5. Van Der Sluis, T.; Pedroli, B.; Frederiksen, P.; Kristensen, S.B.P.; Busck, A.G.; Pavlis, V.; Cosor, G.L. The impact of European landscape transitions on the provision of landscape services: An explorative study using six cases of rural land change. Landsc. Ecol. 2019, 34, 307-323. [CrossRef]

6. Tallis, H.; Goldman, R.; Uhl, M.; Brosi, B. Integrating conservation and development in the field: Implementing ecosystem service projects. Front. Ecol. Environ. 2009, 7, 12-20. [CrossRef]

7. Cremene, C.; Groza, G.; Rakosy, L.; Schileyko, A.A.; Baur, A.; Erhardt, A.; Baur, B. Alterations of Steppe-Like Grasslands in Eastern Europe: A Threat to Regional Biodiversity Hotspots. Conserv. Biol. 2005, 19, 1606-1618. [CrossRef]

8. Poschlod, P.; Bakker, J.P.; Kahmen, S. Changing land use and its impact on biodiversity. Basic Appl. Ecol. 2005, 6, 93-98. [CrossRef]

9. Habel, J.C.; Dengler, J.; Janisova, M.; Torok, P.; Wellstein, C.; Wiezik, M. European grassland ecosystems: Threatened hotspots of biodiversity. Biodivers. Conserv. 2013, 22, 2131-2138. [CrossRef]

10. Antrop, M. The concept of traditional landscapes as a base for landscape evaluation and planning. The example of Flanders Region. Landsc. Urban Plan. 1997, 38, 105-117. [CrossRef]

11. Garbarino, M.; Morresi, D.; Urbinati, C.; Malandra, F.; Motta, R.; Sibona, E.M.; Vitali, A.; Weisberg, P.J. Contrasting land use legacy effects on forest landscape dynamics in the Italian Alps and the Apennines. Landsc. Ecol. 2020, 35, 2679-2694. [CrossRef]

12. Bracchetti, L.; Carotenuto, L.; Catorci, A. Land-cover changes in a remote area of central Apennines (Italy) and management directions. Landsc. Urban Plan. 2012, 104, 157-170. [CrossRef]

13. Aceto, P.; Pividori, M.; Siniscalco, C. Evolution and dynamics of secondary succession in a montane region. Monti Boschi 2000, 51, 4-12.

14. Haller, A.; Bender, O. Among rewilding mountains: Grassland conservation and abandoned settlements in the Northern Apennines. Landsc. Res. 2018, 43, 1068-1084. [CrossRef]

15. De Aranzabal, I.; Schmitz, M.F.; Aguilera, P.; Pineda, F.D. Modelling of landscape changes derived from the dynamics of socio-ecological systems. A case of study in a semiarid Mediterranean landscape. Ecol. Indic. 2008, 8, 672-685. [CrossRef]

16. Mottet, A.; Ladet, S.; Coque, N.; Gibon, A. Agricultural land-use change and its drivers in mountain landscapes: A case study in the Pyrenees. Agric. Ecosyst. Environ. 2006, 114, 296-310. [CrossRef]

17. Kizos, T.; Koulouri, M. Agricultural landscape dynamics in the Mediterranean: Lesvos (Greece) case study using evidence from the last three centuries. Environ. Sci. Policy 2006, 9, 330-342. [CrossRef]

18. Petanidou, T.; Kizos, T.; Soulakellis, N. Socioeconomic Dimensions of Changes in the Agricultural Landscape of the Mediterranean Basin: A Case Study of the Abandonment of Cultivation Terraces on Nisyros Island, Greece. Environ. Manag. 2008, 41, 250-266. [CrossRef]

19. Sitzia, T.; Semenzato, P.; Trentanovi, G. Natural reforestation is changing spatial patterns of rural mountain and hill landscapes: A global overview. For. Ecol. Manag. 2010, 259, 1354-1362. [CrossRef]

20. MacDonald, D.; Crabtree, J.R.; Wiesinger, G.; Dax, T.; Stamou, N.; Fleury, P.; Gutierrez Lazpita, J.; Gibon, A. Agricultural abandonment in mountain areas of Europe: Environmental consequences and policy response. J. Environ. Manag. 2000, 59, 47-69. [CrossRef]

21. Tasser, E.; Tappeiner, U. Impact of land use changes on mountain vegetation. Appl. Veg. Sci. 2002, 5, 173-184. [CrossRef]

22. Dullinger, S.; Dirnböck, T.; Greimler, J.; Grabherr, G. A resampling approach for evaluating effects of pasture abandonment on subalpine plant species diversity. J. Veg. Sci. 2003, 14, 243-252. [CrossRef]

23. Tasser, E.; Tappeiner, U.; Cernusca, A. Ecological Effects of Land-Use Changes in the European Alps. In Global Change and Mountain Regions. Advances in Global Change Research; Huber, U.M., Bugmann, H.K.M., Reasoner, M.A., Eds.; Springer: Dordrecht, The Netherlands, 2005; Volume 23. [CrossRef]

24. Ferretti, F.; Sboarina, C.; Tattoni, C.; Vitti, A.; Zatelli, P.; Geri, F.; Pompei, E.; Ciolli, M. The 1936 Italian Kingdom Forest Map reviewed: A dataset for landscape and ecological research. Ann. Silvic. Res. 2018, 42, 3-19.

25. Geneletti, D. Assessing the impact of alternative land-use zoning policies on future ecosystem services. Environ. Impact Assess. Rev. 2013, 40, 25-35. [CrossRef]

26. Kubacka, M.; Smaga, L. Effectiveness of Natura 2000 areas for environmental protection in 21 European countries. Reg. Environ. Chang. 2019, 19, 2079-2088. [CrossRef]

27. Maes, J.; Barbosa, A.; Baranzelli, C.; Zulian, G.; Batista, F.; Vandecasteele, I.; Hiederer, R.; Liquete, C.; Paracchini, M.L.; Mubareka, S.; et al. More green infrastructure is required to maintain ecosystem services under current trends in land-use change in Europe. Landsc. Ecol. 2015, 30, 517-534. [CrossRef]

28. Guadilla-Sáez, S.; Pardo-de-Santayana, M.; Reyes-García, V. The role of traditional management practices in shaping a diverse habitat mosaic in a mountain region of Northern Spain. Land Use Policy 2019, 89, 104235. [CrossRef] 
29. Queiroz, C.; Beilin, R.; Folke, C.; Lindborg, R. Farmland abandonment: Threat or opportunity for biodiversity conservation? A global review. Front. Ecol. Environ. 2014, 12, 288-296. [CrossRef]

30. Pereira, H.M.; Navarro, L.M. Rewilding Abandoned Landscapes in Europe. In Rewilding European Landscapes; Pereira, H.M., Navarro, L.M., Eds.; Springer: Halle, Germany, 2014; ISBN 978-3-319-12038-6/978-3-319-12039-3. [CrossRef]

31. Laiolo, P.; Dondero, F.; Cilento, E.; Rolando, A. Consequences of pastoral abandonment for the structure and diversity of the alpine avifauna. J. Appl. Ecol. 2004, 41, 294-304. [CrossRef]

32. Fumy, F.; Fartmann, T. Climate and land-use change drive habitat loss in a mountain bird species. Int. J. Av. Sci. 2021, 163, 1189-1206. [CrossRef]

33. Peterken, G.F.; Game, M. Historical Factors Affecting the Number and Distribution of Vascular Plant Species in the woodlands of central Lincolnshire. J. Ecol. 1984, 72, 155-182. [CrossRef]

34. Geri, F.; Rocchini, D.; Chiarucci, A. Landscape metrics and topographical determinants of large-scale forest dynamics in a Mediterranean landscape. Landsc. Urban Plan. 2010, 95, 46-53. [CrossRef]

35. Sartorello, Y.; Pastorino, A.; Bogliani, G.; Ghidotti, S.; Viterbi, R.; Cerrato, C. The impact of pastoral activities on animal biodiversity in Europe: A systematic review and meta-analysis. J. Nat. Conserv. 2020, 56, 125863. [CrossRef]

36. Sitzia, T.; Trentanovi, G. Maggengo meadow patches enclosed by forests in the Italian Alps: Evidence of landscape legacy on plant diversity. Biodivers. Conserv. 2011, 20, 945-961. [CrossRef]

37. Falcucci, A.; Maiorano, L.; Boitani, L. Changes in land-use/land-cover patterns in Italy and their implications for biodiversity conservation. Landsc. Ecol. 2007, 22, 617-631. [CrossRef]

38. Scheurer, T.; Agnoletti, M.; Bürgi, M.; Hribar, M.Š.; Urbanc, M. Exploring Alpine Landscapes as Potential Sites of the Globally Important Agricultural Heritage Systems (GIAHS) Programme. Mt. Res. Dev. 2018, 38, 172-174. [CrossRef]

39. Santoro, A.; Venturi, M.; Bertani, R.; Agnoletti, M. A review of the role of forests and agroforestry systems in the FAO Globally Important Agricultural Heritage Systems (GIAHS) Programme. Forests 2020, 11, 860. [CrossRef]

40. Tscharntke, T.; Klein, A.M.; Kruess, A.; Steffan-Dewenter, I.; Thies, C. Landscape perspectives on agricultural intensification and biodiversity-Ecosystem service management. Ecol. Lett. 2005, 8, 857-874. [CrossRef]

41. Minotti, M.; Giancola, C.; Di Marzio, P.; Di Martino, P. Land Use Dynamics of Drove Roads: The Case of Tratturo Castel di Sangro-Lucera (Molise, Italy). Land 2018, 7, 3. [CrossRef]

42. Di Fazio, S.; Modica, G. Historic Rural Landscapes: Sustainable Planning Strategies and Action Criteria. The Italian Experience in the Global and European Context. Sustainability 2018, 10, 3834. [CrossRef]

43. Malandra, F.; Vitali, A.; Urbinati, C.; Weisberg, P.J.; Garbarino, M. Patterns and drivers of forest landscape change in the Apennines range, Italy. Reg. Environ. Chang. 2019, 19, 1973-1985. [CrossRef]

44. Avram, M. The legacy of transhumance in National Park of Abruzzo lazio and Molise (PNALM) rediscovery and exploitation. GeoJ. Tour. Geosites 2009, 2, 153-159.

45. Malandra, F.; Vitali, A.; Urbinati, C.; Garbarino, M. 70 Years of Land Use/Land Cover Changes in the Apennines (Italy): A meta-analysis. Forests 2018, 9, 551. [CrossRef]

46. Tao, C.; Hu, Y. A Comprehensive Study of the Rational Function Model for photogrammetric processing. Photogramm. Eng. Remote Sens. 2001, 67, 1347-1357.

47. Toutin, T. Review article: Geometric processing of remote sensing images: Models, algorithms and methods. Int. J. Remote Sens. 2004, 25, 1893-1924. [CrossRef]

48. Gasparini, P.; Rizzo, M.; De Natale, F. Manuale di fotointerpretazione per la classificazione delle unità di campionamento di prima fase. In Inventario Nazionale delle Foreste e dei Serbatoi Forestali di Carbonio, INFC2015-Terzo Inventario Forestale Nazionale 2014; Consiglio per la Ricerca e la sperimentazione in Agricoltura, Unità di Ricerca per il Monitoraggio e la Pianificazione Forestale (CRA-MPF); Corpo Forestale dello Stato, Ministero per le Politiche Agricole, Alimentari e Forestali: Roma, Italy, 2014; 64p, ISBN 978-88-97081-73-9.

49. Teferi, E.; Bewket, W.; Uhlenbrook, K.; Wenninger, J. Understanding recent land use and land cover dynamics in the source region of the Upper Blue Nile Ethiopia. Spatially explicit statistical modeling of systematic transitions. Agric. Ecosyst. Environ. 2013, 165, 98-117. [CrossRef]

50. Machado, A. An index of naturalness. J. Nat. Cons. 2004, 12, 95-110. [CrossRef]

51. Garcia Ruiz, J.M.; Lasanta, T.; Nadal-Romero, E.; Lana-Renault, N.; Álvarez-Farizo, B. Rewilding and restoring cultural landscapes in Mediterranean mountains: Opportunities and challenges. Land Use Policy 2020, 99, 104850. [CrossRef]

52. Regos, A.; Dominguez, J.; Gil-Tena, A.; Brotons, L.; Ninyerola, M.; Pons, X. Rural abandoned landscapes and bird assemblages: Winners and losers in the rewilding of a marginal mountain area (NW Spain). Reg. Environ. Chang. 2016, 16, 199-211. [CrossRef]

53. Girao, L.C.; Lopes, A.V.; Tabarelli, M.; Bruna, E.M. Changes in Tree Reproductive Traits Reduce Functional Diversity in a Fragmented Atlantic Forest Landscape. PLoS ONE 2007, 2, e908. [CrossRef]

54. Mattalia, G.; Soukand, R.; Corvo, P.; Pieroni, A. "We became rich and we lost everything": Ethnobotany of remote mountain villages of Abruzzo and Molise, Central Italy. Hum. Ecol. 2021, 49, 217-224. [CrossRef]

55. Antrop, M. Interpreting diversity in the European landscape. A comment on perspective essays by Agnoletti and Schnitzler. Landsc. Urban Plan. 2014, 126, 81-83. [CrossRef]

56. Olwig, K. The Law of Landscape and the Landscape of Law: The Things That Matter. In The Routledge Companion to Landscape Studies; Howard, P., Thompson, I., Waterton, E., Eds.; Routledge: London, UK, 2013; pp. 253-262. 
57. Luginbühl, Y. La Mise en Scène du Monde. Construction du Paysage Européen; CRNS Editions: Paris, France, 2012.

58. Schnitzler, A. Towards a new European wilderness: Embracing unmanaged forest growth and the decolonization of nature. Landsc. Urban Plan. 2014, 126, 74-80. [CrossRef]

59. Agnoletti, M. The degradation of traditional landscape in a mountain area of Tuscany during the 19th and 20th centuries: Implications for biodiversity and sustainable management. For. Ecol. Manag. 2007, 249, 5-17. [CrossRef]

60. Agnoletti, M. Rural landscape, environment and culture: Notes on some research trends and management approaches from a European perspective. Landsc. Urban Plan. 2014, 126, 66-73. [CrossRef]

61. Jongman, R.H.G. Homogenisation and fragmentation of the European landscape: Ecological consequences and solutions. Landsc. Urban Plan. 2002, 58, 211-221. [CrossRef]

62. Piorr, A.; Ungaro, F.; Ciancaglini, A.; Happe, K.; Sahrbacher, A.; Sattler, C.; Uthes, S.; Zander, P. Integrated assessment of future CAP policies: Land use changes, spatial patterns and targeting. Environ. Sci. Policy 2009, 12, 1122-1136. [CrossRef]

63. Renwick, A.; Jansson, T.; Verburg, P.H.; Revoredo-Giha, C.; Britz, W.; Gocht, A.; McCracken, D. Policy reform and agricultural land abandonment in the EU. Land Use Policy 2013, 30, 446-457. [CrossRef]

64. Rega, C.; Helming, J.; Paracchini, M.L. Environmentalism and localism in agricultural and land-use policies can maintain food production while supporting biodiversity. Findings from simulations of contrasting scenarios in the EU. Land Use Policy 2019, 87, 103986. [CrossRef]

65. Métailié, J.P.; Paegelow, M. Land Abandonment and the Spreading of the Forest in the Eastern French Pyrenées in the Nineteenth to Twentieth Centuries. In Recent Dynamics of the Mediterranean Vegetation and Landscape; Mazzoleni, S., di Pasquale, G., Mulligan, M., di Martino, P., Rego, F., Eds.; John Wiley \& Sons Ltd.: Hoboken, NJ, USA, 2004; ISBN 0-470-09369-2. [CrossRef]

66. Sanjuán, Y.; Arnáez, J.; Beguería, S.; Lana-Renault, N.; Lasanta, T.; Gómez-Villar, A.; Álvarez-Martínez, J.; Coba-Pérez, P.; García-Ruiz, J.M. Woody plant encroachment following grazing abandonment in the subalpine belt: A case study in northern Spain. Reg. Environ. Chang. 2018, 18, 1103-1115. [CrossRef]

67. Meyer, M.A.; Fruh-Muller, A. Patterns and drivers of recent agricultural land-use change in Southern Germany. Land Use Policy 2020, 99, 104959. [CrossRef]

68. Reger, B.; Sheridan, P.; Simmering, D.; Otte, A.; Waldhardt, R. Potential effects of direct transfer payments on farmland habitat diversity in a marginal European landscape. Environ. Manag. 2009, 43, 1026-1038. [CrossRef]

69. McGinlay, J.; Gowing, D.J.G.; Budds, J. The threat of abandonment in socio-ecological landscapes: Farmers' motivations and perspectives on high nature value grassland conservation. Environ. Sci. Policy 2017, 69, 39-49. [CrossRef]

70. Lakner, S.; Zinngrebe, Y.; Koemle, D. Combining management plans and payment schemes for targeted grassland conservation within the Habitats Directive in Saxony, Eastern Germany. Land Use Policy 2020, 97, 104642. [CrossRef]

71. Hodgson, J.G.; Montserrat-Martì, G.; Tallowin, J.; Thompson, K.; Diaz, S.; Cabido, M.; Grime, J.P.; Wilson, P.J.; Band, S.R.; Bogard, A.; et al. How much will it cost to save grassland diversity? Biol. Conserv. 2005, 122, 263-273. [CrossRef]

72. Rodriguez-Rodriguez, D.; Larrubia, R.; Sinoga, J.D. Are protected areas good for the human species? Effects of protected areas on rural depopulation in Spain. Sci. Total Environ. 2021, 763, 144399. [CrossRef]

73. Agenzia per la Coesione Territoriale. National Strategy for Inner Areas Strategia Nazionale Per le Aree Interne. LEGGE 27 Dicembre 2013, n. 147. Disposizioni Per la Formazione Del Bilancio Annuale e Pluriennale Dello Stato (Legge di Stabilità 2014) Art. 1, Commi 13-14-15-16-17; Agenzia per la Coesione Territoriale: Rome, Italy, 2013.

74. Garbarino, M.; Sibona, E.M.; Lingua, E.; Motta, R. Decline of Traditional Landscape in a Protected Area of the Southwestern Alps: The Fate of Enclosed Pasture Patches in the Land Mosaic Shift. J. Mt. Sci. 2014, 11, 544-554. [CrossRef]

75. Gillson, L.; Ladle, R.J.; Araújo, M.B. Baselines, Patterns and Process. In Conservation Biogeography, 1st ed.; Ladle, R.J., Whittaker, R.J., Eds.; Blackwell Publishing Ltd.: Hoboken, NJ, USA, 2011.

76. Axelsson, A.L.; Ostlund, L. Retrospective gap analysis in a Swedish boreal forest landscape using historical data. For. Ecol. Manag. 2001, 147, 109-122. [CrossRef] 